\title{
Effect of Trimethoprim-Sulphamethoxazole Combination on Folate Metabolism in Malnourished Children
}

\author{
E. M. E. POSKITT and J. M. PARKIN \\ From the MRC Child Nutrition Unit, Mulago Hospital, Kampala, Uganda
}

\begin{abstract}
Poskitt, E. M. E., and Parkin, J. M. (1972). Archives of Disease in Childhood, 47, 626. Effect of trimethoprim-sulphamethoxazole combination on folate metabolism in malnourished children. The effect of a 10-day course of trimethoprim-sulphamethoxazole on folate metabolism was studied in 10 children with severe protein-calorie malnutrition. There was a significant increase in formimino-glutamic acid (FIGLU) excretion after a histidine load in children treated with trimethoprim-sulphamethoxazole, when compared with a control group, but no haematological evidence of folate deficiency.
\end{abstract}

Trimethoprim (2,4-diamino-5-(3,4,5-trimethoxybenzyl) pyrimidine) inhibits the action of the enzyme dihydrofolate reductase which converts dihydrofolic acid to tetrahydrofolic acid (folinic acid). Tetrahydrofolic acid is essential in both man and bacteria for the formation of formyltetrahydrofolic acid, the 'active one-carbon' unit used in the synthesis of nucleic acids and related compounds. However, the affinity of trimethoprim for bacterial dihydrofolate reductase is 10,000 times that for the enzyme found in man. Sulphonamides, such as sulphamethoxazole, inhibit the synthesis of dihydrofolic acid from para-amino benzoic acid. Man does not carry out this reaction to any appreciable extent, so this action is confined to bacteria. Thus, it is not surprising that combinations of trimethoprim and sulphonamides have a marked effect against a variety of bacterial pathogens (Akinkugbe et al., 1968; Hughes, 1969; Reeves et al., 1969; Pugsley et al., 1969).

In the management of children suffering from protein-calorie malnutrition, intercurrent infection is a major problem (Phillips and Wharton, 1968). Trimethoprim-sulphamethoxazole combinations might, therefore, prove useful in the treatment of infection in such children. However, there are certain theoretical dangers to the widespread use of the drug in these cases, for in many countries a megaloblastic anaemia that responds to treatment with folic acid has been reported in children with

Received 3 February 1972 protein-calorie malnutrition (Scragg and Rubidge, 1960; Kondi et al., 1963). In Uganda this occurs in $12 \%$ of children admitted to hospital with kwashiorkor (Allen and Whitehead, 1965). Consequently, as there have been several reports of effects that may be due to precipitated tetrahydrofolate deficiency in both experimental animals and man after administration of trimethoprim-sulphamethoxazole combinations (Udall, 1969; Whitman, 1969; McCarthy, 1969), it is essential to make certain that trimethoprim-sulphamethoxazole does not cause obvious deterioration in dihydrofolate metabolism in malnourished children, before accepting the drug as a safe antibacterial agent.

\section{Methods}

Investigations were done on 22 children admitted to this unit with kwashiorkor or marasmus for evidence of folate deficiency as shown by formimino-glutamic acid (FIGLU) excretion, bone marrow, and peripheral blood picture. Allen and Whitehead (1965) have shown that children with untreated protein-calorie malnutrition do not excrete FIGLU in the urine, even in the presence of tetrahydrofolate deficiency. A loading dose of histidine is followed by the excretion of abnormal amounts of a precursor of FIGLU, imidazoleacrylic acid. After treatment for 96 hours with a high protein diet the metabolic pathway is restored and FIGLU may then appear in the urine. Initial investigations of folate status in the children were therefore delayed until 4 or 5 days after onset of treatment with a high protein diet. Children then developing infections thought likely to respond were treated with a 10-day course of 


\section{Effect of Trimethoprim-Sulphamethoxazole Combination on Folate Metabolism}

$40 \mathrm{mg}$ trimethoprim and $200 \mathrm{mg}$ sulphamethoxazole twice daily (Bactrim Paediatric Tablets, Roche Products Ltd.), and folate studies were repeated at the end of this course (day 10) and again 10 days later (day 20). The control group were not given the drug, but baseline measurements and repeat assessments were made as with the trimethoprim-sulphamethoxazole group. Otherwise all the children were treated according to Staff (1968). They were also given a single dose of $1 \mathrm{mg}$ intramuscular vitamin B12 (Cytamen, Glaxo-Allenburys) on admission and $60 \mathrm{mg}$ oral ferrous sulphate preparation thrice daily during treatment. Where there was hypochronic anaemia, especially associated with heavy hookworm infestation, $2 \mathrm{ml}$ iron dextran complex (Imferon, Fisons Int.) were given intramuscularly daily for 4 to 8 days. Oral vitamin supplements (Abidec, Parke Davis and Co.) were administered three times a week. Though it has been the practice of this unit for several years to give $5 \mathrm{mg}$ folic acid three times a week to all patients, this was omitted for the purpose of the study. But all the children were treated with $5 \mathrm{mg}$ folic acid daily for at least 2 weeks after the study had been completed.

FIGI.U estimations. The children were given $2 \mathrm{~g}$ histidine orally and urine was collected for the following 24 hours into a bottle containing $3 \mathrm{ml}$ concentrated hydrochloric acid. 25-100 of $\mu \mathrm{l}$ each urine sample were applied in duplicate to two separate sheets of Whatman 20 chromatography paper. The papers were subjected to ascending chromatography for 20 hours in a butanol acid-water solvent (12:3:5 by volume). After drying, they were examined for imidazoleacrylic acid in ultraviolet light. One of the papers was then placed in an atmosphere of ammonia for 1 hour to convert any FIGLU to glutamic acid. Excess ammonia was blown off with a small fan. Both chromatograms were treated with ninhydrin followed by ethanolic copper nitrate, as described by Whitehead (1964). In urine samples containing FIGLU an extra spot appeared in the chromatogram which had been in ammonia. This area was cut out and placed in a boiling tube. The corresponding area of the nonammoniated paper was similarly treated. The salmon pink colours of both areas were eluted and their extinctions measured at $509 \mathrm{~nm}$. The difference in the colour densities was assumed to be due to FIGLU, and the actual quantity in the specimens was calculated from a standard curve prepared from authentic FIGLU treated in the same way.

Haematological investigations. $\mathrm{Hb}$ was estimated by the cyanmethaemoglobin method. Red and white cell counts were carried out by the Coulter Counter Model F. Platelet counts were performed using 'Coulter platelet kits' and a $70 \mu$ aperture according to Bull, Schneiderman, and Brecher (1965). Mean corpuscular volumes were estimated on the Coulter Counter equipped with a mean cell volume computer and the percentage of cells with volume greater than $110 \mu^{3}$ was determined (Pruden and Winstead, 1963). Neutrophil counts and neutrophil mean lobe counts were obtained from thin blood films stained with Leishman's stain. Bone marrow specimens were aspirated from the iliac crest.

\section{Results}

There were 10 children in the group treated with trimethoprim-sulphamethoxazole ('trimethoprim' group) and 12 children in the group not given the drug ('control' group) (Table I). Table II lists the infections treated with trimethoprim-sulphamethoxazole. Infections in the control group were treated with appropriate antibiotics.

FIGLU estimations. A series of three 24hour urine specimens was obtained from 9 children in the trimethoprim group and 10 children in the control group. No child excreted significant amounts of imidazoleacrylic acid in any specimen. 24-hour FIGLU excretion estimations for individual children are shown in Table III. A significant rise in mean FIGLU excretion occurred only in the trimethoprim group. 10 days after cessation of the drug, this had fallen but was still significantly higher than the initial level. There was a slight but statistically insignificant rise in mean FIGLU excretion in the control group during the study.

Haematology. At no time was there any significant difference in the $\mathrm{Hb}$, red cell count, platelet count, mean corpuscular volume, or percentage of

TABLE I

Comparison of Trimethoprim and Control Groups

\begin{tabular}{l|c|c}
\hline & Trimethoprim Group & \\
\hline No. of children & 10 & 12 \\
Sex & $5 \mathrm{M} ; 5 \mathrm{~F}$ & $6 \mathrm{M} ; 6 \mathrm{~F}$ \\
Age & $10 / 12-44 / 12$ & $9 / 12-48 / 12$ \\
Type of malnutrition & 9 kwashiorkor, 1 marasmus & 10 kwashiorkor, 2 marasmic kwashiorkor \\
$\begin{array}{l}\text { Number of infections treated with antibacterial agents } \\
\text { Result of treatment of malnutrition }\end{array}$ & 10 & 9 \\
& All recovered & \\
& & \\
\end{tabular}


TABLE II

Infections Treated with Trimethoprim-Sulphamethoxazole

\begin{tabular}{|c|c|c|c|c|}
\hline $\begin{array}{l}\text { Case } \\
\text { No. }\end{array}$ & Infection & Causative Organ & $\begin{array}{l}\text { Sensitivity to } \\
\text { Trimethoprim }\end{array}$ & Response to Treatment \\
\hline $\begin{array}{l}1 \\
2 \\
3 \\
4\end{array}$ & $\begin{array}{l}\text { Gastroenteritis } \\
\text { Otitis media } \\
\text { Gastroenteritis } \\
\text { Measles (initially treated as } \\
\text { respiratory tract infection) }\end{array}$ & $\begin{array}{l}\text { None isolated } \\
\text { Mixed coliforms } \\
\text { Pathogenic Esch. coli } \\
\text { Measles virus }\end{array}$ & $\begin{array}{l}\text { Partial } \\
\text { Yes } \\
\text { No }\end{array}$ & $\begin{array}{l}\text { Complete recovery } \\
\text { No change } \\
\text { Complete recovery } \\
\text { Progressed to severe hronchopneu- } \\
\text { monia; cough swab grew Klebsiella } \\
\text { resistant to trimethoprim; } \\
\text { recovered after treatment with } \\
\text { tetracycline }\end{array}$ \\
\hline $\begin{array}{l}5 \\
6\end{array}$ & $\begin{array}{l}\text { Tonsillitis } \\
\text { Infected meibomian cyst with } \\
\text { cellulitis of eyelid }\end{array}$ & $\begin{array}{l}\text { C. diphtheriae } \\
\text { Staph. aureus }\end{array}$ & $\begin{array}{l}\text { Yes } \\
\text { Yes }\end{array}$ & $\begin{array}{l}\text { Complete recovery } \\
\text { Complete recovery }\end{array}$ \\
\hline $\begin{array}{r}7 \\
8 \\
9 \\
10\end{array}$ & $\begin{array}{l}\text { Bronchopneumonia } \\
\text { Pharyngitis } \\
\text { Urinary tract infection } \\
\text { Pharyngitis }\end{array}$ & $\begin{array}{l}\text { None isolated } \\
\text { C. diphtheriae } \\
\text { Esch. coli. } \\
\text { C. diphtheriae }\end{array}$ & $\begin{array}{l}\text { Yes } \\
\text { Yes } \\
\text { Yes }\end{array}$ & $\begin{array}{l}\text { Complete recuvery } \\
\text { Complete recovery } \\
\text { Complete recovery† } \\
\text { Complete recovery }\end{array}$ \\
\hline
\end{tabular}

^All three stains of corynebacteria were eventually shown to be avirulent.

tThis child had a total of 6 weeks of antibacterial treatment of the urinary infection, only the first 10 days being with trimethoprim- $\bigcirc$ sulphamethoxazole.

red cells greater than $110 \mu^{3}$ volume between the two groups of children (Table IV). There was a rise in $\mathrm{Hb}$, red cell, and platelet counts in all children. During the first $\mathbf{1 0}$ days this was greater in the control than the trimethoprim group, but the differences reached possible significance only in the red cell count $(t=2 \cdot 1, P=<0 \cdot 05)$. White cell counts were extremely variable. Some children in both groups showed neutropenia with neutrophil counts less than $2000 / \mathrm{mm}^{3}$. However, this is a frequent finding in children with proteincalorie malnutrition. Mean neutrophil lobe counts showed no significant difference throughout the study. All marrows were normoblastic with no abnormalities of the red or white cell series. Megakaryocytes appeared normal. Thus, despite abnormal excretion of FIGLU, there was no haematological evidence of tetrahydrofolate deficiency.

\section{Discussion}

The children treated with trimethoprim-sulphamethoxazole were not suffering from severe infections, so it is not possible to assess fully the place of trimethoprim-sulphamethoxazole in the treatment of infections in malnourished children. Nevertheless, this small series showed the drug to be useful. Wherever the organisms being treated

TABLE III

FIGLU Excretion mg/24 Hours in Individual Children

\begin{tabular}{|c|c|c|c|c|c|c|c|}
\hline \multicolumn{4}{|c|}{ Trimethoprim Group } & \multicolumn{4}{|c|}{ Control Group } \\
\hline Case No. & Day 0 & Day 10 & Day 20 & Case No. & Day 0 & Day 10 & Day 20 \\
\hline $\begin{array}{l}1 \\
2 \\
3 \\
4 \\
5 \\
6 \\
7 \\
8 \\
9\end{array}$ & $\begin{array}{r}12 \cdot 1 \\
1 \cdot 0 \\
2 \cdot 5 \\
29 \cdot 5 \\
0 \cdot 0 \\
24 \cdot 9 \\
25 \cdot 5 \\
3 \cdot 2 \\
3 \cdot 0\end{array}$ & $\begin{array}{r}139 \cdot 6 \\
40 \cdot 6 \\
77 \cdot 3 \\
113 \cdot 5 \\
0 \cdot 0 \\
49 \cdot 9 \\
0 \cdot 0 \\
1 \cdot 0 \\
175 \cdot 0\end{array}$ & $\begin{array}{r}76 \cdot 5 \\
68 \cdot 1 \\
23 \cdot 5 \\
71 \cdot 1 \\
36 \cdot 7 \\
96 \cdot 4 \\
2 \cdot 3 \\
0 \cdot 8 \\
120 \cdot 0\end{array}$ & $\begin{array}{r}1 \\
2 \\
3 \\
4 \\
5 \\
6 \\
7 \\
8 \\
9 \\
10\end{array}$ & $\begin{array}{r}0 \cdot 0 \\
5 \cdot 1 \\
14 \cdot 0 \\
2 \cdot 2 \\
50 \cdot 6 \\
66 \cdot 1 \\
48 \cdot 7 \\
0 \cdot 9 \\
27 \cdot 1 \\
4 \cdot 6\end{array}$ & $\begin{array}{r}14 \cdot 6 \\
25 \cdot 9 \\
48 \cdot 0 \\
21 \cdot 7 \\
15 \cdot 2 \\
114 \cdot 6 \\
26 \cdot 3 \\
0 \cdot 0 \\
43 \cdot 5 \\
1 \cdot 2\end{array}$ & $\begin{array}{r}30 \cdot 9 \\
41 \cdot 8 \\
11 \cdot 6 \\
11 \cdot 2 \\
0 \cdot 0 \\
228 \cdot 0 \\
0 \cdot 5 \\
0 \cdot 0 \\
50 \cdot 0 \\
5 \cdot 1\end{array}$ \\
\hline $\begin{array}{l}\text { Mean } \\
\text { SE }\end{array}$ & $\begin{array}{r}11 \cdot 3 \\
4 \cdot 0\end{array}$ & $\begin{array}{l}66 \cdot 3 \\
21 \cdot 5^{\star}\end{array}$ & $\begin{array}{l}55 \cdot 0 \\
13 \cdot 8 t\end{array}$ & & $\begin{array}{r}21 \cdot 9 \\
7 \cdot 9\end{array}$ & $\begin{array}{l}29 \cdot 1 \\
10 \cdot 8 \ddagger\end{array}$ & $\begin{array}{l}37 \cdot 91 \\
21 \cdot 88 \ddagger\end{array}$ \\
\hline
\end{tabular}

*Significantly different using paired ' $\mathrm{t}$ ' test from Day 0 value, $P<0.05$. tSignificantly different from Day 0 value, $P<0.02$.

$\ddagger$ Not significantly different from Day 0 value. 
Effect of Trimethoprim-Sulphamethoxazole Combination on Folate Metabolism

TABLE IV

Haematological Values in Trimethoprim and Control Groups with Standard Error of Mean

\begin{tabular}{|c|c|c|c|c|c|c|c|}
\hline & Day & $\begin{array}{l}\mathrm{Hb} \\
\mathrm{g} \%\end{array}$ & $\begin{array}{l}\text { Red Cell Count } \\
\times 10^{6} / \mathrm{mm}^{3}\end{array}$ & $\begin{array}{c}\text { Mean } \\
\text { Corpuscular } \\
\text { Volume } / \mathrm{mm}^{3}\end{array}$ & $\begin{array}{c}\text { Percentage } \\
\text { Cells } \\
\text { Greater } \\
\text { Than } 110 \mu^{3}\end{array}$ & $\begin{array}{l}\text { Platelet Count } \\
\times 10^{3} / \mathrm{mm}^{3}\end{array}$ & $\begin{array}{l}\text { Neutrophil } \\
\text { Count/mm }\end{array}$ \\
\hline $\begin{array}{l}\text { Trimethoprim } \\
\text { group }\end{array}$ & $\begin{array}{r}0 \\
10 \\
20\end{array}$ & $\begin{array}{r}8 \cdot 0( \pm 0 \cdot 3) \\
9 \cdot 5( \pm 0 \cdot 3) \\
10 \cdot 4( \pm 0 \cdot 3)\end{array}$ & $\begin{array}{l}3 \cdot 17( \pm 0 \cdot 19) \\
3 \cdot 33( \pm 0 \cdot 09) \\
3 \cdot 99( \pm 0 \cdot 11)\end{array}$ & $\begin{array}{l}89( \pm 4) \\
88( \pm 3) \\
88( \pm 2)\end{array}$ & $\begin{array}{l}15( \pm 4) \\
14( \pm 3) \\
14( \pm 2)\end{array}$ & $\begin{array}{l}348( \pm 35) \\
417( \pm 46) \\
449( \pm 34)\end{array}$ & $\begin{array}{l}4040( \pm 482) \\
3645( \pm 473) \\
3687( \pm 590)\end{array}$ \\
\hline
\end{tabular}

^No significant difference between trimethoprim and control groups.

were fully sensitive to trimethoprim, complete recovery occurred. Further, no child had vomiting or other side effects attributable to the drug.

Ideally, a study of the effect of trimethoprim on the folate metabolism of these children should have included estimation of serum folate levels. However, these could not be measured. We therefore had to rely on FIGLU excretion after a loading dose of histidine for biochemical evidence of folate deficiency. FIGLU excretion may be increased in deficiency of vitamin B12 or iron (Kohn, Mollin, and Rosenbach, 1961; Knowles and Prankerd, 1962; Vitale, Streiff, and Hellerstein, 1965), but all the children in this study were given intramuscular vitamin $\mathrm{B} 12$ on admission and oral iron throughout the study, so deficiences of these factors are unlikely to have affected the results. Liver disease may also be associated with abnormal FIGLU excretion (Carter et al., 1961). The liver in kwashiorkor is grossly fatty, and decreased activity of glutamate-formiminotransferase could account for the abnormal FIGLU excretion in the early days after admission. Yet all the children responded well to treatment with the high protein diet so it is unlikely that increases in FIGLU excretion were due to deteriorating liver function. So, it is probable that any significant increase in mean FIGLU excretion in these children reflected a reduced availability of tetrahydrofolic acid.

The actual pattern of FIGLU excretion in the children varied widely. Some never excreted significant amounts and presumably had no deficiency of tetrahydrofolate. In others the initial high FIGLU excretion decreased during the study without folic acid supplements. However, the diet of a milk preparation and steamed banana was by no means free of folic acid. This may have corrected initial deficiency of tetrahydrofolate in children whose dihydrofolate reductase was active. Other children, predominantly in the drug-treated group, showed high FIGLU excretion both on day 10 and day 20. It appears that these children were unable to maintain adequate levels of tetrahydrofolate. In children treated with trimethoprim this is likely to be due to inhibition of dihydrofolate reductase by the drug.

The tendency for $\mathrm{Hb}$, red cell, and platelet counts to rise more slowly during treatment with trimethoprim also suggests some deficiency of tetrahydrofolate with this treatment. However, the absence of any definite haematological signs of folate deficiency indicates that this drug is reasonably safe to use in malnourished children. Dormandy, Waters, and Mollin (1963) suggested that the absence of megaloblastic change in many children with coeliac disease, despite almost invariably low serum folate and high FIGLU excretion, was due to relative folate sparing by cessation of growth. But the children in this study are growing at a very high rate, often as much as $70 \mathrm{~g}$ per day. Demand for tetrahydrofolate in these children must have been great. Therefore, the most likely explanation for the difference between the biochemical and haematological results is that there was insufficient time for the development of haematological evidence of folate deficiency. Had the trimethoprim-sulphamethoxazole been given for a longer period, the stress on folate metabolism might have produced haematological abnormalities.

In view of this, perhaps some reservations on the use of the drug are indicated. Mitchell (1970) has suggested that trimethoprim-sulphamethoxazole could become the first choice antibacterial agent in the treatment of urinary tract infections in children. Long-term use of the drug will then be likely. It would be advisable, therefore, to prescribe prolonged courses of the drug to malnourished children-and others susceptible to folate deficiency - only if close monitoring of the bone marrow and peripheral blood is possible. 
This investigation was the original suggestion of Professor R. Blowers, recently of the Department of Microbiology, Makerere University, Kampala, Uganda. We are grateful to the scientific, nursing, and technical staff of the unit, especially Dr. W. A. Coward and Mr. A. Makwaya who performed the haematological measurements. The bone marrow specimens were examined by Dr. W. Walker, Department of Child Health, Newcastle upon Tyne.

\section{REFERENCES}

Akinkugbe, O. O., Lewis, E. A., Montefiore, D., and Okubadejo, O. A. (1968). Trimethoprim and sulphamethoxazole in typhoid. British Medical fournal, 3, 721.

Allen, D. M., and Whitehead, R. G. (1965). The excretion of urocanic acid and formimino glutamic acid in megaloblastosis accompanying kwashiorkor. Blood, 25, 283.

Bull, B. S., Schneiderman, M. A., and Brecher, G. (1965). Platelet counts with the Coulter counter. American fournal of Clinical Pathology, 44, 678.

Carter, F. C., Heller, P., Schaffner, G., and Korn, R. J. (1961). Formiminoglutamic acid (FIGLU) excretion in hepatic cirrhosis. Archives of Internal Medicine, 108, 41.

Dormandy, K. M., Waters, A. H., and Mollin, D. L. (1963). Folicacid deficiency in coeliac disease. Lancet, $1,632$.

Hughes, D. T. D. (1969). Single-blind comparative trial of trimethoprim-sulphamethoxazole and ampicillin in the treatment of exacerbations of chronic bronchitis. British Medical fournal, $4,470$.

Knowles, J. P., and Prankerd, T. A. J. (1962). Abnormal folic acid metabolism in vitamin $\mathrm{B}_{12}$ deficiency. Clinical Science, 22, 233.

Kohn, J., Mollin, D. L., and Rosenbach, L. M. (1961). Conventional voltage electrophoresis for formiminoglutamic-acid determination in folic acid deficiency. Fournal of Clinical Pathology, 14, 345.
Kondi, A., MacDougall, L., Foy, H., Mehta, S., and Mbaya, v. (1963). Anaemias of marasmus and kwashiorkor in Kenya. Archives of Disease in Childhood, 38, 267.

McCarthy, O. R. (1969). Neutropenia after trimethoprim- 0 sulphamethoxazole for bronchitis. (Letter.) British Medicalo fournal, 3, 113.

Mitchell, R. G. (1970). The sulphonamides in childhood. Practi- $\frac{\bar{\sigma}}{\overline{0}}$ tioner, 204, 20.

Phillips, I., and Wharton, B. (1968). Acute bacterial infection in $\overparen{\Phi}$ kwashiorkor and marasmus. British Medical fournal, 1, 407.

Pruden, E. L., and Winstead, M. E. (1963). Blood cell counts by Coulter counter. Proceedings of the 31st Annual ASMT Convention, Denver, Colorado.

Pugsley, D. J., Mwanje, L., Pearson, C., and Blowers, R. (1969). Use of trimethoprim and sulphamethoxazole in tropical Africa. $\overrightarrow{ }$ Postgraduate Medical fournal, 45, Suppl. (Nov.), 95.

Reeves, D. S., Faiers, M. C., Pursell, R. E., and Brumfitt, w. (1969). Trimethoprim-sulphamethoxazole: comparative study in urinary infection in hospital. British Medical fournal, 1, 541. O

Scragg, J., and Rubidge, C. (1960). Kwashiorkor in African A children in Durban. British Medical fournal, 2, 1759.

Staff, T. H. E. (1968). Treatment of severe kwashiorkor and marasmus in hospital. East African Medical fournal, 45, 399.

Udall, V. (1969). Toxicology of sulphonamide-trimethoprim combinations. Postgraduate Medical fournal, 45, Suppl. N (Nov.), 42.

Vitale, J. J., Streiff, R. R., and Hellerstein, E. E. (1965). Folate $ᄋ$ metabolism and iron deficiency. (Letter.) Lancet, 2, 393.

Whitehead, R. G. (1964). Rapid determination of some plasma aminoacids in subclinical kwashiorkor. Lancet, 1, 250.

Whitman, E. N. (1969). Effects in man of prolonged administration of trimethoprim and sulfisoxazole. Postgraduate Medical $\frac{\bar{A}}{\oplus}$ fournal, 45, Suppl. (Nov.), 46.

Correspondence to Dr. J. M. Parkin, The Children's Department, The Royal Victoria Infirmary, Newcastle ? upon Tyne NE1 4LP. 